\title{
Application of Filtration to Recover Solubilized Proteins During pH-Shift Processing of Blue Whiting (Micromesistius poutassou); Effects on Protein Yield and Qualities of Protein Isolates
}

\author{
Helgi Nolsøe*,a, Sofia K. Marmon ${ }^{\mathrm{b}}$ and Ingrid Undeland ${ }^{\mathrm{b}}$ \\ ${ }^{a}$ Faroe Marine Research Institute, Nóatún 1, FO-110 Tórshavn, Faroe Islands \\ ${ }^{b}$ Chalmers University of Technology, Chemical and Biological Engineering-Food Science, SE 41296 Göteborg, Sweden
}

\begin{abstract}
Previous studies of the $\mathrm{pH}$-shift protein isolation process have shown that substantial amounts of solubilized proteins can be trapped in the sediments formed in the first centrifugation step of this process. As a strategy to improve the protein yield during $\mathrm{pH}$-shift processing, the aim of this study was to evaluate how filtration as an alternative to centrifugation in the first separation step of $\mathrm{pH}$-shift processing of blue whiting affected proteins yield and protein isolate characteristics (basic composition, polypeptide profiles, surimi gel quality and color attributes). The study comprised both the acid and alkaline versions of the method, and also fresh as well as frozen fish raw material. Results showed that the replacement of centrifugation with filtration substantially improved the protein yield by from about $38 \%$ to $62 \%$, but also reduced the removal of lipid. There were no significant effects on gel quality. Protein isolates from fresh raw material were about $5 \%$ whiter and frozen raw materials about $3 \%$ whiter with centrifugation as compared to filtration in the $\mathrm{pH}-$ shift process. For surimi from fresh raw material centrifugation gave about $2 \%$ whiter gels, while the gels from frozen raw material were about $3 \%$ whiter for filtered compared to centrifuged material. The whitest isolates and gels were obtained with acid processing of fresh blue whiting. Slight proteolytic breakdown resulting in fragments of 83 and $152 \mathrm{kDa}$ was however noted with the acid process, especially when centrifugation was used.
\end{abstract}

Keywords: Protein isolate, surimi, blue whiting, yield, gel strength, filtration, centrifugation.

\section{INTRODUCTION}

Blue whiting, see Fig. (1). is one of the big fish resources suitable for human consumption. Traditionally, however most blue whiting has been used for fish-meal production due to its small size and the difficulties involved in processing it economically for human consumption. Currently, a reduction in the blue whiting quotas has forced ship owners to find new ways to increase the revenue for each $\mathrm{kg}$ of caught fish. One of the solutions that increases the value of the raw-material is to increase the portion destined for human consumption, e.g. through surimi production. One of the general drawbacks with classic surimi production is, however, the relatively low protein yields. A literature review undertaken by Nolsøe and Undeland [1], found that the average protein yield from seven studies of traditional surimi processing of different fish species was about $56 \%$. On the other hand, 13 and 14 studies of the acid and alkaline versions of the $\mathrm{pH}$-shift process revealed average protein yields of $70 \%$ and $67 \%$, respectively. When running the $\mathrm{pH}$-shift processes without the first centrifugation step (thus when just adjusting the $\mathrm{pH}$ down and up or up and down); average protein yields of $86 \%$, and $84 \%$ were reported from 3 acid and 4 alkaline $\mathrm{pH}$-shift studies, respectively Nolsøe and Undeland [1]. Of course these protein isolates become less pure since non-dissolved material is not removed. Further, Undeland et al. [2] described how processing of herring light

*Address correspondence to this author at the Faroe Marine Research Institute, Nóatún 1, FO-110 Tórshavn, Faroe Islands; Tel: +298353949; Fax: +298353901; E-mail: Helgino@ hav.fo muscle resulted in the formation of a large gel-like extra sediment during the first centrifugation step that trapped a relatively large part of the dissolved proteins. Thus, avoiding this large sediment formation would improve the protein yields substantially.

In this context the question of filtration (or sieving), as a replacement for centrifugation in the first separation step, becomes very interesting. Filtration may remove nondissolved proteins and impurities, and at the same time improve the yield compared to centrifugation. It could therefore be of high interest for surimi producers. Recently, Nolsøe et al. [3], for the first time showed that filtration can be a promising alternative to centrifugation during the alkaline $\mathrm{pH}$ shift processing of fresh cod, pollock and mackerel muscle. This study showed that protein yields were significantly increased when the first centrifugation step was replaced by filtration. However, the surimi gel quality was decreased. Replacing the second centrifugation with filtration had no effect on yield or quality. It was thus concluded that filtration could be a promising alternative when superior gel quality is not the prime aim. As a continuation of this study, the concept of filtration is here evaluated during both the acid and alkaline versions of the $\mathrm{pH}$-shift process, and also with both fresh and pre-frozen fish muscle. Using frozen fish rawmaterial, especially when considering land-based processing, is another important issue that could be of benefit for surimi producers as the use of frozen raw material would afford the opportunity to even out production over a longer period. In the present study, we have also taken into consideration the abilities of a filtration-based process to remove lipids and 


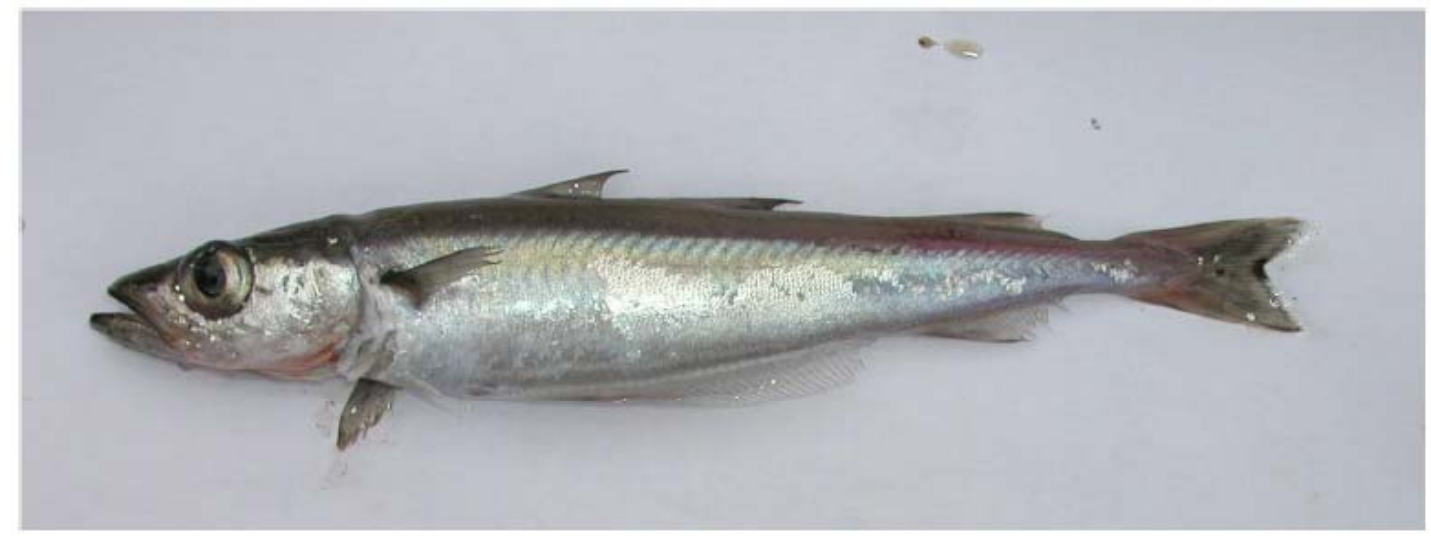

Fig. (1). Blue whiting (Micromesistius poutassou) photographed by Rógvi Mouritsen.

pigments, something which has not previously been reported.

The overall aim of this study was to evaluate if filtration can be an alternative to centrifugation during the first separation step of the acid and alkaline versions of the $\mathrm{pH}$-shift process using both fresh and frozen blue whiting (Micromesistius poutassou). To evaluate this, the following parameters of the process were considered: protein yield, lipid removal, moisture content of the isolate, quality of surimi gels produced from the isolates, and color of the protein isolates and the surimi gels.

\section{MATERIAL AND METHODS}

\section{Materials}

Fresh whole blue whiting (Micromesistius poutassou), caught in the North Atlantic by blue whiting trawlers in the period from January to May in 2008 and 2009 with a post mortem age of 12- 48 hours, were off-loaded immediately upon arrival at port. Each batch was about $8-14 \mathrm{~kg}$ and the length of the fish was generally between 23 and $40 \mathrm{~cm}$. The fish were kept iced during the one hour it took to arrival at the laboratory. Here, it was manually beheaded and gutted. The fish for the frozen fish experiments was frozen in $2 \mathrm{~kg}$ portions in freezing bags at $-80{ }^{\circ} \mathrm{C}$ and remained stored for approximately four months. Prior to $\mathrm{pH}$-shift processing, the frozen fish were thawed out in a refrigerator overnight. At the time of processing for protein isolation, the fish were manually filleted, de-skinned, and ground. The grinding was performed in a Bear Varimixer ( Type AR10 from A/S Wodschow \& Co, Brøndby, Denmark) equipped with a $70 \mathrm{~mm}$ Meat Mincer with a $4.5 \mathrm{~mm}$ hole-plate. The weight yield of headed and gutted fish was $61.1 \pm 0.4 \%(n=4)$ and the weight yield of ground meat was $36.0 \pm 3.5 \%(n=4)$.

\section{Protein Isolation Using the pH-Shift Process}

The $\mathrm{pH}$-shift procedure that was followed, and the points at which samples were taken out, are illustrated in Fig. (2). Ground muscle, $1.5 \mathrm{~kg}$, was mixed with six parts of cold demineralised water $\left(4^{\circ} \mathrm{C}\right)$ and homogenized with a Pro Scientiffic Model Pro 250 homogenizer (Oxford, Connecticut, USA) at $75 \%$ of the maximum speed for $30 \mathrm{sec}$. The homogenate was split in two equal portions. The $\mathrm{pH}$ of the two portions was adjusted from its initial value, generally between 6.5 and 7.0, to $\mathrm{pH} 10.8$ and 2.5 by drop-wise adding 2
$\mathrm{M} \mathrm{NaOH}$ and $2 \mathrm{M} \mathrm{HCl}$, respectively. Each of the two portions was then further split in two portions, one for centrifugation, and one for filtration. The centrifugation was performed for $20 \mathrm{~min}$ at $10000 \mathrm{x} \mathrm{g}$ in a Sigma $4 \mathrm{~K} 15$ centrifuge (Buch \& Holm, Herlev, Denmark). The temperature of the centrifuge was kept at $4{ }^{\circ} \mathrm{C}$ during the centrifugation. After centrifugation the undissolved material was separated from the dissolved material by decanting the dissolved material through a double layer of 24/20 cheese cloth (Alphasource Inc, Philadelphia, Pennsylvania, USA). Filtration as a method to separate dissolved from undissolved material was carried out with a 200 x $50 \mathrm{~mm}$ stainless steel test sieve (Retsch, SkanLab ApS, Slangerup, Denmark) with a $1 \mathrm{~mm}$ mesh opening.

To precipitate the dissolved proteins, the $\mathrm{pH}$ of the centrifugation supernatant and filtrate was then adjusted to $\mathrm{pH}$ 5.5 by drop wise addition of $2 \mathrm{M} \mathrm{NaOH}$ and $2 \mathrm{M} \mathrm{HCl}$ to the acidic and alkaline samples, respectively. After precipitation, the material was kept refrigerated for about 10 min until it was centrifuged for $20 \mathrm{~min}$ at $10000 \mathrm{x} \mathrm{g}$ at $4^{\circ} \mathrm{C}$ to settle the precipitated proteins. After centrifugation, the process-water was poured off from the centrifuging bottles, and the protein isolate was collected in a container and kept in a refrigerator at $4{ }^{\circ} \mathrm{C}$. The moisture content of the protein isolate was then further reduced by wrapping it in a double layer of fine meshed heavy cheese cloth before subjecting it to pressure in a manual screw press. The four isolates were pressure dewatered at the same time. Following this procedure, moisture contents of between $70-77 \%$ were reached. It should be stressed that all materials were kept cool with ice during the entire $\mathrm{pH}$-shift processing.

\section{Preparation of Surimi Gels}

The moisture content of the dewatered protein isolates was adjusted to $80 \%$ with water before addition of $4 \%$ sucrose, $4 \%$ sorbitol, and $0.3 \%$ sodium tripolyphosphate (ww) as cryoprotectants. The additions were mixed in with a precooled Braun Combimax 600 (LM, Torshavn, Faroe Islands) mixer equipped with a knife. The $\mathrm{pH}$ of the material was adjusted to $\mathrm{pH} 7$ by adding $2 \mathrm{M} \mathrm{NaOH}$ to the water used for adjusting the moisture content. The material was then packed in freeze-tolerant plastic bags and frozen at $-80^{\circ} \mathrm{C}$. The resultant surimi was placed in freezer for some 60 hours, after which it was partially thawed and cut into approximately 20 $\mathrm{mm}$ pieces and minced in the Braun Combimax 600 and 




Fig. (2). The process diagram illustrates how the pH-shift process was run, and at what points during the process samples were taken for analysis. Details about the process are given in the materials and methods section.

mixed with $2 \% \mathrm{NaCl}(\mathrm{w} / \mathrm{w})$. The mixing was continued until the temperature of the material reached $7-8^{\circ} \mathrm{C}$ and the material was then stuffed into $\varnothing 27 \mathrm{~mm}$ plastic casings. The cas- ings were cooked at $90^{\circ} \mathrm{C}$ for 40 min thereafter the casings were immersed in cold running water for at least one hour. 
The casings were then stored at room temperature for 18-24 hours before testing.

\section{Protein Content Determination and Calculation of Pro- tein Solubility as well as Protein Recovery}

The protein contents of the raw material, the homogenate, the filtrate, the supernatant, the residues and the isolates were measured using the Biuret method [4].

In order to calculate protein solubility following acidification and alkalization, the protein concentration in the supernatant or filtrate fraction was divided by the protein concentration in the non-centrifuged or non-filtered homogenate sample.

The protein recovery was calculated as: (protein concentration of protein isolate X Weight protein isolate)/ (protein concentration of homogenate $\mathrm{X}$ weight of homogenate)*100.

Qualitative Protein Analysis Using Sodium Dodecyl Sulfate Polyacrylamide Gel Electrophoresis (SDS-PAGE)

One g samples of blue whiting mince and isolates from frozen fish were homogenized on ice with 9 volumes of $2 \mathrm{M}$ $\mathrm{NaOH}$ using an Ultra Turrax T18 Basic homogenizer (IKA, Taquara, RJ, Brazil). Further dilution was performed with $0.1 \mathrm{M} \mathrm{NaOH}$ until the protein concentration was approximately $2 \mathrm{mg} / \mathrm{ml}$. The diluted samples were mixed with one part Laemmlli buffer prepared with 5\% $\beta$-mecaptoethanol, and were denatured by heating in boiling water for $5 \mathrm{~min}$. After denaturation, the samples were centrifuged for $3 \mathrm{~min}$ at $2000 \mathrm{~g}$ in an Eppendorf 5415 centrifuge (Eppendorf, Hamburg, Germany). A sample volume containing $15 \mu \mathrm{g}$ proteins was then added to each well of the electrophoresis gels (precast linear 4-20\% PageR Gold gradient gels, Lonza Aps, Copenhagen, Denmark). The gels were run for $80 \mathrm{~min}$ in a vertical C.B.S Scientific CO electrophoresis tool (Del Mar, California, USA) with a constant voltage of $120 \mathrm{~V}$ supplied by a PowerPac TM Basic from BioRad (Sundbyberg, Sweden). The molecular weight standards used had a range of 6.5-200 kDa (Protein marker III, VWR, Copenhagen, Denmark). After running, the gels were washed in distilled water for five min and fixated in a solution of $10 \%$ acetic acid and $10 \%$ methanol in for $2 \times 15 \mathrm{~min}$. After the fixation the gel was stained for $60 \mathrm{~min}$ in Coomassie G-250 (BioRad, Sundbyberg, Sweden) staining solution. The staining solution was made of $100 \mathrm{ml}$ acetic acid, $0.25 \mathrm{~g}$ Coomassie Blue and 900 $\mathrm{ml}$ of distilled water. The destaining was performed $3 \times 10$ $\min$ in $40 \%$ acetic acid before washing overnight in distilled water. The gel was scanned in a GS-800 Calibrated Densitometer (BioRad).

\section{Determination of Lipid Content}

The fat content of the raw material and the protein isolates was determined using extraction with chloroform and methanol according to Lee et al. [5].

\section{Determination of Moisture Content}

The moisture content of the raw materials and protein isolates was measured on $\sim 3 \mathrm{~g}$ sample using a Chyo Model IB-30 moisture balance (Sun Scientific Co Ltd., 4-Chome, Kamiyoga, Setagaya-KU, Tokyo, Japan).

\section{Testing of Gel Strength}

The procedure used for testing gel strength (breaking force and deformation) has been described in the Japanese grading standards Kim [6]. Thirty $\mathrm{mm}$ slices of the surimi gels were used together with a Rheo Tex type SD 700 (Sun Scientific Co Ltd.,4-Chome, Kamiyoga, Setagaya-KU, Tokyo, Japan) having a $5.0 \mathrm{~mm}$ probe set at $60 \mathrm{~mm} / \mathrm{min}$.

\section{Analysis of Color}

The color of the raw material, isolates (after adjusting the moisture to $80 \%$ ) and surimi gels was analyzed using a Minolta CR-300 (77781007) and a Minolta Data processor DP 301 (77721067, Konica Minolta Sensing Americas, Inc., New Jersey, USA). The tools were calibrated using a Minolta calibration plate. The color of the raw material and isolates was measured by filling a square plastic container $(5 \times 5 \times 1) \mathrm{cm}$ with ground meat and measuring at 10 different points on the surface.

The color measurements of the surimi gels were performed by measuring the color at the surface of 10 different slices cut from the specimens used for gel strength measurements.

The whiteness of the mince, protein isolates and gels were calculated using the Whiteness 1 formula:

$$
\mathrm{W}=100-\left((100-\mathrm{L} *)^{2}+\mathrm{a}^{* 2}+\mathrm{b}^{*^{2}}\right)^{1 / 2}[7]
$$

\section{Statistics}

Each process version (acid process with centrifugation, acid process with filtration, alkaline process with centrifugation and alkaline process with filtration) was repeated three times with fresh raw material and three times with frozen raw materials. When analyzing color and gel strength 10 replicate samples from each process run were tested. For protein-, lipid-, and moisture content analyses, three replicate samples were selected. The statistical calculations have been performed with PASW Statistics 18, (Chicago, Illinois, USA) using ANOVA and Tukey`s HSD multiple rank test to determine significant differences between groups. Differences were regarded as significant when $p<0.05$. A t test was used to test differences between results from processing of frozen vs. fresh raw material. The graphics have been made with ABC FlowCharter 3, Micrografx, Inc.

\section{RESULTS}

\section{Protein Yield Using Different Processing Versions with Either Fresh or Frozen Blue Whiting}

The results in Table $\mathbf{1}$ show that the average protein yields for the $\mathrm{pH}$-shift process with filtration $(73.4 \pm 6.2 \%$ $82.7 \pm 4.0 \%$ ) were higher than the protein yields obtained with centrifugation $(47.2 \pm 9.7 \%-58.7 \pm 12.6 \%)$. For the runs made with frozen fish, this difference was significant. There was no significant difference in protein yield between the uses of fresh vs. frozen fish and between the uses of acid vs. alkaline solubilization. The size (\% of wet weight) of the sediments formed via centrifugation was typically from $18 \%$ to $40 \%$ while the size of the filter cake formed via filtration was 3 to $11 \%$. Since both sediments and the filter cake were high in moisture content, this illustrates why less solubilized proteins could be recovered when centrifugation was used. 
Table 1. Protein yields (mean \pm SD) using either centrifugation or filtration in the first separation step with alkaline or acid pHshift processing of fresh and frozen blue whiting. " $n$ " is the number of runs made with each process version. Results within the same column carrying different letters indicate a significant difference $(p<0.05)$

\begin{tabular}{|c|c|c|c|c|}
\hline \multirow{2}{*}{$\begin{array}{c}\text { Sample } \\
(\mathbf{n}=\mathbf{3})\end{array}$} & \multirow{2}{*}{$\begin{array}{c}\text { Isolation } \\
\text { method }\end{array}$} & \multirow{2}{*}{$\begin{array}{l}\text { Separation } \\
\text { method }\end{array}$} & \multicolumn{2}{|c|}{ Protein yield } \\
\hline & & & Fresh fish & Frozen fish \\
\hline \multirow{4}{*}{$\begin{array}{l}\text { Protein } \\
\text { isolate }\end{array}$} & \multirow[t]{2}{*}{ Alkaline } & Centrifugation & $51.3 \pm 15.2^{\mathrm{ab}}$ & $51.1 \pm 1.7^{\mathrm{a}}$ \\
\hline & & Filtration & $81.3 \pm 8.6^{\mathrm{bc}}$ & $82.7 \pm 3.9^{\mathrm{b}}$ \\
\hline & \multirow[t]{2}{*}{ Acid } & Centrifugation & $47.2 \pm 9.7^{\mathrm{a}}$ & $58.7 \pm 12.6^{\mathrm{a}}$ \\
\hline & & Filtration & $73.4 \pm 6.2^{\mathrm{abc}}$ & $81.2 \pm 0.9^{b}$ \\
\hline
\end{tabular}

Table 2. Composition of water, protein and lipids (mean \pm SD) for blue whiting mince and protein isolates derived from either centrifugation or filtration in the first separation step with alkaline or acid pH-shift processing of fresh and frozen blue whiting. " $n$ " is the number of runs of each process version with frozen and fresh raw material. Results within the same column carrying different letters indicate a significant difference $(p<0.05)$

\begin{tabular}{|c|c|c|c|c|c|c|c|c|}
\hline \multirow{2}{*}{$\begin{array}{l}\text { Samples } \\
\qquad(n=3)\end{array}$} & \multirow{2}{*}{$\begin{array}{c}\text { Isolation } \\
\text { method }\end{array}$} & \multirow{2}{*}{ Separation method } & \multicolumn{2}{|c|}{ Moisture (\%) } & \multicolumn{2}{|c|}{ Protein $(\%) \mathrm{dw}$} & \multicolumn{2}{|c|}{ Lipid (\%) dw } \\
\hline & & & Fresh fish & Frozen fish & Fresh fish & Frozen fish & Fresh fish & Frozen fish \\
\hline Mince & - & - & $79.4 \pm 0.1^{\mathrm{a}}$ & $78.6 \pm 2.2^{\mathrm{a}}$ & $86.3 \pm 1.0^{\mathrm{a}}$ & $81.4 \pm 8.8^{\mathrm{a}}$ & $4.7 \pm 0.7^{\mathrm{ab}}$ & $2.8 \pm 0.6^{\mathrm{a}}$ \\
\hline \multirow{4}{*}{$\begin{array}{l}\text { Protein } \\
\text { isolate }\end{array}$} & \multirow{2}{*}{ Alkaline } & Centrifugation & $71.8 \pm 2.5^{\mathrm{a}}$ & $69.8 \pm 5.9^{\mathrm{b}}$ & $94.3 \pm 1.8^{\mathrm{a}}$ & $87.8 \pm 14.4^{\mathrm{a}}$ & $2.3 \pm 0.6^{\mathrm{c}}$ & $2.3 \pm 1.6^{\mathrm{a}}$ \\
\hline & & Filtration & $69.8 \pm 2.3^{\mathrm{a}}$ & $70.5 \pm 1.4^{\mathrm{b}}$ & $89.1 \pm 1.4^{\mathrm{a}}$ & $91.4 \pm 7.4^{\mathrm{a}}$ & $6.2 \pm 0.1^{\mathrm{bd}}$ & $5.3 \pm 2.0^{\mathrm{ab}}$ \\
\hline & \multirow{2}{*}{ Acid } & Centrifugation & $75.9 \pm 7.1^{\mathrm{a}}$ & $74.7 \pm 0.8^{\mathrm{ab}}$ & $92.7 \pm 1.6^{\mathrm{a}}$ & $93.7 \pm 1.7^{\mathrm{a}}$ & $3.6 \pm 1.0^{\mathrm{ac}}$ & $5.7 \pm 1.9^{\mathrm{ab}}$ \\
\hline & & Filtration & $77.6 \pm 2.1^{\mathrm{a}}$ & $73.2 \pm 1.1^{\mathrm{ab}}$ & $89.9 \pm 0.9^{\mathrm{a}}$ & $92.5 \pm 10.7^{\mathrm{a}}$ & $7.0 \pm 0.6^{\mathrm{d}}$ & $7.4 \pm 1.0^{\mathrm{b}}$ \\
\hline
\end{tabular}

\section{Composition of Blue Whiting Mince and Protein Isolates}

Table 2 shows the basic composition of the fresh and frozen minces, as well as of the protein isolates made thereof. It should be stressed here that the fresh raw material used was caught in January and February while the frozen raw material used was caught in May, explaining why the basic compositions of the fresh and frozen raw materials differ. Higher protein and lipid contents were found in the freshly- used raw material.

There were no significant differences in moisture contents between the protein isolates obtained with the four process versions when applied to fresh raw material. Using frozen raw material, the alkaline processes gave isolates with significantly lower moisture content than the isolates from the acid process.

The protein analyses showed no significant differences in protein content between the protein isolates, whether using fresh or frozen raw material. When testing the protein contents of all isolates from fresh raw material against those from the frozen raw material, it was seen that isolates from frozen raw material contained significantly more protein. This is because of lower moisture content.

Using fresh raw material, isolates made with the centrifugation process had lower lipid contents than the starting mince (significant for the alkaline process). On the contrary, isolates made via the filtration process had higher lipid levels. In 3 out of 4 cases, the lipid contents of the protein iso- lates from the centrifugation process was significantly lower than isolates made via the filtration process.

\section{Color of Mince, Protein Isolates and Cooked Surimi from} Fresh and Frozen Blue Whiting

Color data for protein isolates and surimi gels made from fresh raw-material are shown in Table 3. The corresponding values for the frozen raw material are shown in Table 4. Color measurements for fresh raw materials show that all isolates have higher whiteness than the starting mince, and all surimi gels have higher whiteness than protein isolates. This is mainly because of higher lightness in respectively isolates and surimi gels. The measurements also show a tendency to higher whiteness for acid processed isolates and surimi gels. There is also a tendency that filtration has lower whiteness than centrifugation.

Also the measurement for frozen raw material show that all isolates have higher whiteness than the starting mince, but the whiteness of the surimi gels were at the same level, or in two cases lower than for the isolates (alkaline and acid centrifugation).

For the surimi gels, significantly higher $\mathrm{a}^{*}$ - values and significantly lower $b^{*}$-values are for centrifugation compared to filtration.

Comparing data for fresh and frozen raw material show that 3 of 4 isolates from the fresh raw material have higher $b^{*}$ values. For the surimi gels fresh raw material show higher $\mathrm{L}^{*}$ and whiteness values. 
Table 3. Lightness $\left(\mathrm{L}^{*}\right)$, redness $\left(\mathrm{a}^{*}\right)$, yellowness $\left(\mathrm{b}^{*}\right)$ and whiteness $(\mathrm{W})$ for blue whiting mince as well as protein isolates and surimi gels derived from either centrifugation or filtration in the first separation step with alkaline or acid pH-shift processing of fresh blue whiting. "n" is the number of runs of each process version. Results within the same column carrying different letters indicate a significant difference $(p<0.05)$

\begin{tabular}{|c|c|c|c|c|c|c|}
\hline $\begin{array}{c}\text { Samples } \\
(\mathbf{n}=\mathbf{3})\end{array}$ & $\begin{array}{l}\text { Isolation } \\
\text { method }\end{array}$ & $\begin{array}{c}\text { Separation } \\
\text { method }\end{array}$ & $\mathbf{L}^{*}$ & $\mathbf{a}^{*}$ & $\mathbf{b}^{*}$ & W \\
\hline Mince & - & - & $45.0 \pm 3.5^{\mathrm{a}}$ & $1.4 \pm 1.1^{\mathrm{a}}$ & $6.7 \pm 1.5^{\mathrm{a}}$ & $44.6 \pm 3.7^{\mathrm{a}}$ \\
\hline \multirow{3}{*}{$\begin{array}{l}\text { Protein } \\
\text { isolate }\end{array}$} & \multirow[t]{2}{*}{ Alkaline } & Centrifugation & $56.4 \pm 8.3^{\mathrm{bc}}$ & $0.1 \pm 1.8^{\mathrm{a}}$ & $6.0 \pm 2.3^{\mathrm{ab}}$ & $55.9 \pm 8.2^{\mathrm{bc}}$ \\
\hline & & Filtration & $53.4 \pm 5.0^{\mathrm{ab}}$ & $-0.1 \pm 0.4^{\mathrm{ab}}$ & $6.1 \pm 0.2^{\mathrm{ab}}$ & $53.0 \pm 4.9^{\mathrm{ab}}$ \\
\hline & Acid & Filtration & $62.6 \pm 4.8^{\mathrm{bcd}}$ & $-0.7 \pm 0.2^{a b c}$ & $6.9 \pm 1.0^{\mathrm{a}}$ & $62.0 \pm 4.9^{\mathrm{bcc}}$ \\
\hline \multirow{3}{*}{$\begin{array}{l}\text { Surimi } \\
\text { gels* }\end{array}$} & \multirow[t]{2}{*}{ Alkaline } & Centrifugation & $69.5 \pm 6.8^{\text {de }}$ & $-3.5 \pm 0.1^{\mathrm{d}}$ & $1.5 \pm 0.7^{\mathrm{c}}$ & $69.2 \pm 6.7^{\text {de }}$ \\
\hline & & Filtration & $69.6 \pm 1.3^{\text {de }}$ & $-2.1 \pm 0.2^{\mathrm{bd}}$ & $5.6 \pm 1.2^{\mathrm{ab}}$ & $69.0 \pm 1.2^{\text {de }}$ \\
\hline & Acid & Centrifugation & $75.8 \pm 0.2^{\mathrm{e}}$ & $-3.2 \pm 0.7^{\mathrm{d}}$ & $2.2 \pm 1.8^{\mathrm{bc}}$ & $75.4 \pm 0.2^{\mathrm{e}}$ \\
\hline
\end{tabular}

*surimi gels contained $21.6 \%$ total dry matter.

Table 4. Lightness $\left(\mathrm{L}^{*}\right)$, redness $\left(\mathrm{a}^{*}\right)$, yellowness $\left(\mathrm{b}^{*}\right)$ and whiteness $(\mathrm{W})$ for blue whiting mince as well as protein isolates and surimi gels derived from either centrifugation or filtration in the first separation step with alkaline or acid pH-shift processing of frozen blue whiting. " $n$ " is the number of runs of each process version. Results within the same column carrying different letters indicate a significant difference $(p<0.05)$

\begin{tabular}{|c|c|c|c|c|c|c|}
\hline $\begin{array}{c}\text { Samples } \\
\quad(\mathbf{n}=\mathbf{3})\end{array}$ & $\begin{array}{c}\text { Isolation } \\
\text { method }\end{array}$ & $\begin{array}{c}\text { Separation } \\
\text { method }\end{array}$ & $\mathbf{L}^{*}$ & $\mathbf{a}^{*}$ & $\mathbf{b}^{*}$ & $\mathbf{W}$ \\
\hline Mince & - & - & $47.6 \pm 2.8^{\mathrm{a}}$ & $2.0 \pm 0.4^{\mathrm{a}}$ & $7.2 \pm 0.8^{\mathrm{a}}$ & $47.0 \pm 2.8^{\mathrm{a}}$ \\
\hline \multirow{2}{*}{$\begin{array}{l}\text { Protein } \\
\text { isolate }\end{array}$} & \multirow[t]{2}{*}{ Alkaline } & Centrifugation & $62.3 \pm 0.3^{b}$ & $1.9 \pm 0.1^{\mathrm{a}}$ & $6.3 \pm 0.1^{\mathrm{ab}}$ & $61.7 \pm 0.3^{b}$ \\
\hline & & Filtration & $59.6 \pm 0.8^{\mathrm{bc}}$ & $0.3 \pm 0.3^{b}$ & $5.7 \pm 0.4^{\mathrm{ab}}$ & $59.2 \pm 0.8^{\mathrm{bc}}$ \\
\hline \multirow{3}{*}{$\begin{array}{l}\text { Surimi } \\
\text { gels* }\end{array}$} & \multirow[t]{2}{*}{ Alkaline } & Centrifugation & $56.0 \pm 1.9^{\mathrm{c}}$ & $-3 \pm 0.9^{e}$ & $0.4 \pm 1.8^{\mathrm{d}}$ & $55.9 \pm 1.9^{\mathrm{c}}$ \\
\hline & & Filtration & $60.3 \pm 0.9^{b}$ & $-1.8 \pm 0.3^{\text {cd }}$ & $4.8 \pm 0.4^{\mathrm{abc}}$ & $59.9 \pm 0.9^{\mathrm{bc}}$ \\
\hline & Acid & Centrifugation & $61.0 \pm 1.2^{b}$ & $-3.0 \pm 0.0^{\mathrm{e}}$ & $2.5 \pm 1.1^{\mathrm{cd}}$ & $60.8 \pm 1.1^{b}$ \\
\hline
\end{tabular}

*Surimi contain $27.5 \%$ total dry matter.

\section{Gel Strength for Surimi Gels from Fresh and Frozen Blue Whiting}

Breaking force $(\mathrm{g})$ and deformation $(\mathrm{mm})$ results for surimi gels made from fresh and frozen raw material are shown in Table 5. It should be stressed that these two sets of gels cannot be directly compared as gels from the fresh raw material had lower dry- matter content than gels from the frozen raw material (21.6\% instead of $27.5 \%)$. Taking both sets of gels into consideration, three out of four cases showed a non-significant tendency towards lower breaking force and deformation values for the isolates made with filtration instead of centrifugation. No other general differences could be seen. It should be mentioned that large variations in the results from breaking force analyses could indicate varia- tions in the quality of the raw material. The age of the fresh raw material varied from 12 to 48 hours and the age of the frozen raw material varied from 12 to 24 hours before it was landed.

\section{Electrophoresis Evaluation of the Gel Proteins}

To determine if there were some qualitative protein differences in isolates made with filtration compared to centrifugation, and with the acid vs. the alkaline process, an SDS-PAGE analysis of the four types of isolates was performed. The results are shown in Fig. (3), with the referenced differences marked with arrows. There was a slight tendency towards more dense bands in the very high MWregion (>>200 kDa) for alkali-made isolates (lanes 3-4) than 
Table 5. Breaking force and deformation values (mean \pm SD) for cooked surimi gels from isolates made from fresh and frozen blue whiting. " $n$ " is the number of runs with each process version. Results within the same column carrying different letters indicate a significant difference $(p<0.05)$. The gels made from fresh fish contain $21.6 \%$ total dry material and the gels made from frozen fish contain $27.5 \%$ total dry material

\begin{tabular}{|c|c|c|c|c|c|c|}
\hline \multirow{2}{*}{$\begin{array}{c}\text { Samples } \\
(\mathbf{n}=\mathbf{3})\end{array}$} & \multirow{2}{*}{ Isolation method } & \multirow{2}{*}{ Separation method } & \multicolumn{2}{|c|}{ Breaking force (g) } & \multicolumn{2}{|c|}{ Deformation (mm) } \\
\hline & & & Fresh fish & Frozen fish & Fresh fish & Frozen fish \\
\hline \multirow{4}{*}{ Surimi gels } & \multirow{2}{*}{ Alkaline } & Centrifugation & $331 \pm 180^{\mathrm{abc}}$ & $622 \pm 264^{\mathrm{c}}$ & $10.7 \pm 0.8^{\mathrm{a}}$ & $10.4 \pm 1.8^{\mathrm{a}}$ \\
\hline & & Filtration & $223 \pm 22^{\mathrm{ab}}$ & $515 \pm 104^{\mathrm{abc}}$ & $9.5 \pm 1.4^{\mathrm{a}}$ & $8.3 \pm 1.0^{\mathrm{a}}$ \\
\hline & \multirow{2}{*}{ Acid } & Centrifugation & $149 \pm 63^{a}$ & $717 \pm 224^{\mathrm{c}}$ & $9.8 \pm 1.1^{\mathrm{a}}$ & $10.8 \pm 0.8^{a}$ \\
\hline & & Filtration & $174 \pm 54^{a}$ & $573 \pm 29^{\mathrm{bc}}$ & $8.3 \pm 0.9^{\mathrm{a}}$ & $9.2 \pm 1 . .^{4 a}$ \\
\hline
\end{tabular}

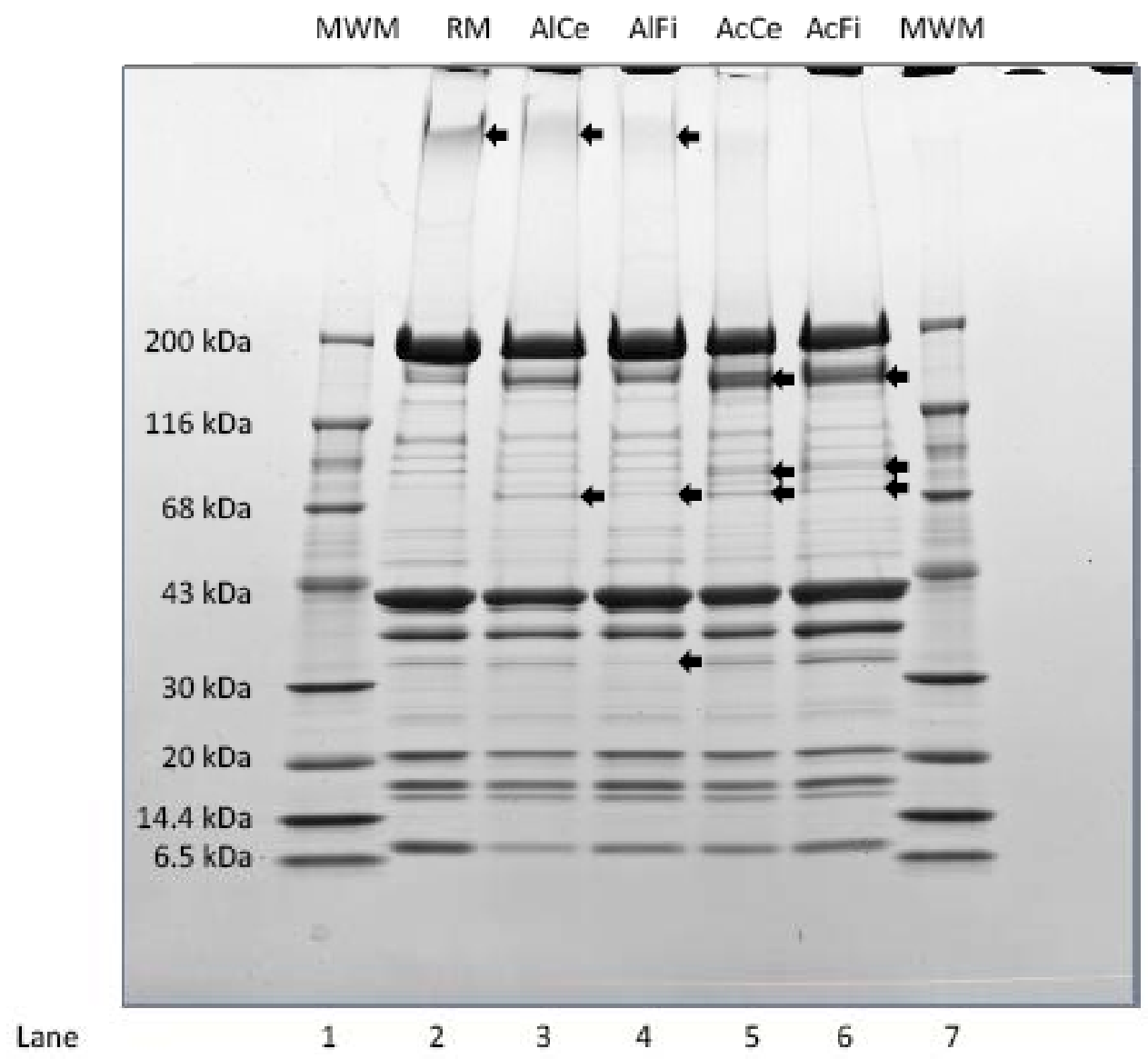

Fig. (3). SDS-PAGE (4-20\% linear gradient) of blue whiting muscle protein isolates produced with different versions of the pH shift method. Lane 1 (MWM): Molecular weight standards 6.5-200 kDa. Lane 2 (RM): Blue whiting mince. Lane 3 (AlCe): Alkaline processed centrifuged protein isolate. Lane 4(AlFi): Alkaline processed filtrated protein isolate. Lane 5 (AcCe): Acid processed centrifuged protein isolate. Lane 6 (AcFi): Acid-processed filtered protein isolate. Lane 7 (MWM): Molecular weight markers 6.5-200 kDa. $15 \mu \mathrm{g}$ protein were loaded into each well, except for the standards where $10 \mu \mathrm{g}$ were loaded. Polypeptides marked with an arrowhead are mentioned in the results and discussion.

for the acid-made isolates (lane 5-6), particularly with centrifugation as the separation method (lane 3). The acid-made protein isolates also gave rise to more dense bands at about $83 \mathrm{kDa}$ and $152 \mathrm{kDa}$. In all isolates, there was also a band at around $72 \mathrm{kDa}$, which was absent in the raw material (lane 2). Finally, the isolate made with alkaline processing and filtration (lane 4) almost completely lacked a band at 32 $\mathrm{kDa}$, tentatively identified as tropomyosin $\alpha$.

\section{DISCUSSION}

The main purpose of this paper has been to evaluate how changing from centrifugation to filtration in the first separation step of the $\mathrm{pH}$-shift method affect protein yield and quality of blue whiting protein isolates. Using both process versions, a comparison between the acid and alkaline versions of the $\mathrm{pH}$-shift method was also conducted as well as, a comparison between the use of fresh and frozen blue whiting 
mince. The application of high-speed centrifugation in the $\mathrm{pH}$-shift method has partly been a strategy to remove lipids. Particularly the membrane lipids appear to demand high gforces in order to sediment out. Lipid removal, if fully accomplished, can reduce the risks for rancidity and also allows for the removal of lipid-soluble contaminants like dioxins and dioxin-like PCB's. [8] In spite of these potential advantages, a main driving force behind changing from centrifugation to filtration has been the relatively large amounts of proteins that often are trapped in the sediments formed during centrifugation of acidified/alkalized muscle homogenates Undeland et al. [2]. These sediments are connected to the high viscosity of the $\mathrm{pH}$-adjusted homogenates which in turn originates in expansion and partial solvation of protein aggregates. It has been reported that these sediments become particularly large with stored and/or frozen fish. Within the surimi industry, there is a current wish to increase the use of frozen raw material to even out production throughout the year. It should also be stressed that centrifugation is a costly process operation, and the use of filtration could be a major simplification of the $\mathrm{pH}$-shift method for isolating protein.

The results of this study are set out in Table 1 show that the protein yields when using filtration compared to centrifugation became higher both for acid and alkaline processing and for both fresh and frozen raw-materials. The increase in yield was up to $60 \%$, and is explained by the smaller fraction of the solubilized proteins being trapped in the filter cake, as compared to entrapment in the sediments derived from centrifugation. The present findings are in line with those previously reported by Nolsøe et al. [3], although the average protein yields in that study generally were higher (90\% with filtration and $71.7 \%$ with centrifugation). The protein yields obtained with frozen blue whiting are similar to those obtained with fresh blue whiting. This stands in contrast to the findings of Undeland et al. [2]. Undeland found that sediments formed during centrifugation of acidified and alkalized herring homogenates were much larger with frozen raw material, and thus, much more of the solubilized proteins remained trapped in the sediment. Thus as pointed out by Nolsøe and Undeland [1], there are large differences in the response of different fish species to acid and alkaline solubilization and precipitation.

As expected, the lipid content of the protein isolates derived from filtration was higher than that found in protein isolates derived from centrifugation (Table 2). However, the literature indicates that, it is likely that the difference in lipid levels between isolates made with filtration vs. centrifugation is not likely to affect the development of rancidity. For example, Undeland et al. [9] showed that painty odour and TBARS developed at equal rates in washed cod mince fortified with $3 \mu \mathrm{M} \mathrm{Hb}$ and $0,7.5$ or $15 \%$ non stabilized fish oil. That the lipid content of isolates made with filtration was higher than the lipid content of the raw material is consistent with the findings of Undeland et al. [10] from a study in which they tested the acid process without any separation of insoluble matter at all. This is a consequence of a larger removal of proteins than lipids.

An important aspect of both fish protein isolates and surimi is color. Generally, the whiter the isolate/surimi, the higher the market interest. Discoloration problems generally come from the presence of melanin, e.g. from eyes and skin, as well as from the hemoglobin and myoglobin of blood and dark muscle. As reviewed by Nolsøe and Undeland [1], several studies have shown that the isolates from the $\mathrm{pH}$-shift process are less pigmented than the raw material used. This was also seen in our study here, both for isolates and surimi gels. A few previous studies have also compared the $\mathrm{pH}$-shift process with and without the centrifugation step [11, 12]; Undeland et al. [10]. In two of these previous studies, the isolates from the $\mathrm{pH}$-shift process showed greater pigmentation when centrifugation was omitted. However, three studies showed less pigmentation when centrifugation was omitted. Our replacement of centrifugation with filtration showed, weak tendencies towards less whiteness (isolates from fresh raw material). In addition, in isolates from frozen raw-material, we observed greater yellowness and redness with filtration rather than with centrifugation. This fact was noted for both isolates and surimi gels and could possibly be explained by the ability of hydrophobic heme goups to coprecipitate with lipids into the sediments formed via centrifugation [11]. The somewhat higher whiteness values for isolates, derived from the acid process opposed to the alkaline process, are quite unusual. In the review by Nolsøe and Undeland [1] 13 out of 17 studies reported whiter isolates with the alkaline process over the acid process. A deeper investigation by Kristinsson et al. [11] on this topic revealed that more native heme-proteins remained soluble at $\mathrm{pH} 5.5$ with the alkaline process than the acid process when applied to channel catfish.

The small tendency towards weaker and less elastic surimi gels from isolates derived with filtration rather than centrifugation (Table 5) was in line with a previous study by Nolsøe [3] although differences found in that study were significant. A contributing explanation could be the slightly higher lipid content of the isolates made with filtration Nolsøe [13]. When the surimi gels are made, the isolates are adjusted to the same dry matter content. Since both proteins and lipids contribute to the dry matter, the slightly higher lipid content of the isolates derived from filtration thus contributed to a slightly lower protein content of those gels. This small difference could have been a contributing factor to the slightly lower gel strength.

In study by Nolsøe et al. [3] another hypothesis was lined out to explain the higher gel forming abilities of centrifugation produced isolates compared to filtration produced. In this paper, both the sediment and supernatant from the first centrifugation were studied with SDS-PAGE. It was notified that four polypeptides were concentrated in the sediment fraction $(116,109,95$ and $31 \mathrm{kDa})$, two of which remained in the sediment even after a second re-suspension and centrifugation of the sediment (109 and 116). It was suggested that these polypeptides may aid aggregation of the other proteins, e.g. by cross-linking. Two of them (95 and $31 \mathrm{kDa})$ were tentatively identified as $\alpha$-actinin and troponin $\mathrm{T}$, respectively, both being involved with binding proteins of the Z-discs and the thin filaments. From the SDS-PAGE analyses of the four types of isolates produced in this study (Fig. 3 ), it was not possible to detect any clear polypeptide differences that could explain the better gel- forming abilities after centrifugation compared to filtration. Possibly the band detected at $72 \mathrm{kDa}$ was slightly more dense in isolates derived from centrifugation. This band was not detected in the raw 
material, and is, therefore, most likely a degradation product that remained in solution during the first centrifugation. Overall, the clearest differences found in the SDS-PAGE gels were instead the tendency to proteolytic breakdown during acid, as compared to alkaline processing. Breakdown fragments were found both around 83 and $152 \mathrm{kDa}$. The same results have previously been shown by Undeland et al. [14], where the proteolysis at $\mathrm{pH} 2.7$ was even more pronounced.

\section{CONCLUSIONS}

This paper shows that replacing centrifugation with filtration improves the protein yield substantially both for fresh and frozen blue whiting without significantly affecting the quality of surimi gels. This is an opportunity to make future surimi production more sustainable with a better utilization of the raw material.

The study also shows that less fat was removed with filtration than with centrifugation, and also that the color became somewhat darker, especially with frozen raw material.

In future work, investigations should be made into the influence of the lipid content on the gel quality and the possible methods to improve the gel quality and the color of protein isolates from frozen raw material.

\section{ACKNOWLEDGEMENT}

Thanks is extended to the personnel at Food Science, Chalmers, for valuable assistance.

\section{REFERENCES}

[1] Nolsøe H, Undeland I. The acid and alkaline solubilization process for the isolation of muscle proteinsstate of the art. Food Bioprocess Technol 2009; 2: 1-27.

[2] Undeland I, Kelleher SD, Hultin HO, McClements J, Thongraung C. Consistency and Solubility Changes in Herring (Clupea harengus) Light Muscle Homogenates as a Function of pH. J Agric Food Chem 2003; 51(14): 3992-8.
[3] Nolsøe H, Imer S, Hultin HO. Study of phase separation by filtration instead of centrifugation affects protein yield and gel quality during an alkaline solubilization process- different surimiprocessing methods. Intern J Food Sci Technol 2007; 42: 139-47.

[4] Robinson HW, Hogden CG. The biuret reaction in the determination of serum proteins. J Biol Chem 1940; 135: 707-25.

[5] Lee CM, Trevino B, Chaiyawat M. A simple and rapid solvent extraction method for determinig total lipids in fish tissue. J AOAC Intern 1995; 79(2): 1996.

[6] Kim BY, Park JW, Yoon WB. Rheology and texture properties of surimi gels. surimi and surimi seafood. 2 ed. Boca Raton, London, New York, Singapore: Taylor \& Francis; 2005; pp. 491-582.

[7] Park JW. Ingredient Technology for Surimi and Surimi Seafood In: Park JW, editor. Surimi and Surimi Seafood. 2 ed. Boca Raton, London, New York, Singapore: Taylor \& Francis; 2005. p. 649707.

[8] Marmon SK, Liljelind P, Undeland I. Removal of lipids, dioxins, and polychlorinated biphenyls during production of protein isolates from baltic herring (Clupea harengus) using $\mathrm{pH}$-shift processes. J Agric Food Chem 2009; 57(17): 7819-25.

[9] Undeland I, Hultin HO, Richards MP. Added triacylglycerols do not hasten hemoglobin-mediated lipid oxidation in washed minced cod muscle. J Agric Food Chem 2002; 50(23): 6847-53.

[10] Undeland I, Hall G, Wendin K, Gangby I, Rutgersson A. Preventing lipid oxidation during recovery of functional proteins from herring (Clupea harengus) fillets by an acid solubilization process. J Agric Food Chem 2005; 53(14): 5625-34.

[11] Kristinsson HG, Theodore AE, Demir N, Ingadottir B. A comparative study between acid- and alkali- aided processing and surimi processing for the recovery of proteins from channel catfish muscle. J Food Sci 2005; 70(4): 298-306.

[12] Kristinsson HG, Demir N. Functional fish protein ingredients from fish species of warm and temperate waters: comparisons of acidand alkali- aided processing vs conventional surimi processing. In: Bechtel PJ, Ed. Advances in Seafood Byproducts. Anchorage: Alaska Sea Grant College Program 2002; pp. 277-95.

[13] Nolsøe H. Sildesurimi og fremstilling ombord på fabriksskib. Aalborg: Aalborg University; 1987.

[14] Undeland I, Kelleher SD, Hultin HO. Recovery of functional proteins from herring (Clupea harengus) light muscle by an acid or alkaline solubilization process. J Agric Food Chem 2002; 50(25): 7371-9.

(C) Nolsøe et al.; Licensee Bentham Open.

This is an open access article licensed under the terms of the Creative Commons Attribution Non-Commercial License (http://creativecommons.org/licenses/by-nc/3.0/) which permits unrestricted, non-commercial use, distribution and reproduction in any medium, provided the work is properly cited. 